\title{
POTRET JURNAL ELEKTRONIK TERAKREDITASI BIDANG PERPUSTAKAAN DOKUMENTASI DAN INFORMASI DI INDONESIA
}

\author{
Rochani Nani Rahayu ${ }^{1}$; Sensusiyati ${ }^{1}$ \\ ${ }^{1}$ Pusat Data dan Dokumentasi Ilmiah LIPI \\ Korespondensi: nanipdii1@gmail.com
}

Diajukan: 02-10-2020; Direview: 18-10-2020; Direvisi: 23-10-2020; Diterima: 14-12-2020

\begin{abstract}
Descriptive research on electronic journals in the field of library and information sciences in Indonesia, aims to determine 1) the number of accredited electronic journals, 2) journal publishers which are divided into a) state and private Islamic universities; b) public and private universities; c) non-tertiary institutions; d) professional associations; 2) City of published journals; 3) whether the journal site is active or not; 4) Frequency of journal publication and 5) Journal accreditation status. Data were collected from the data base http://issn.pdii.lipi.go.id/ and http://sinta. ristekbrin.go.id by searching using library keywords, documentation and information. Furthermore, the data were grouped according to research objectives. The results showed that the number of journals was 41 titles, published by 37 publishers. A total of 15 titles were published by state / private Islamic universities, followed by 14 titles by public / private universities, 7 titles by non-tertiary institutions, and 5 titles by professional associations. Journals are published in 21 cities, and Jakarta is in the highest position (19.51\%), the National Library of the Republic of Indonesia is in the first rank as the largest journal publisher (3 titles). The most frequent publication of journals is twice per year (85.36\%). Since March 1, 2020, as many as 31 sites are active (accessible), and the rest are inactive. A total of 13 journals have accredited status. The highest accreditation is SINTA 2 (3 titles). It is concluded that the electronic library library information journal as of March 2020 is known to be 41 titles, published by 37 publishers. Most publishers come from non-Islamic state universities and the National Library of the Republic of Indonesia is the largest publisher. Jakarta is the highest city of publication. Most of the frequency of publication of journals is twice per year, not all electronic journal websites can be accessed as of March 11, 2020, and based on the accreditation status it is known that there is no journal with SINTA 1 accreditation status.
\end{abstract}

Keywords: Journals; Library and Information Science; Accreditation

\begin{abstract}
ABSTRAK
Penelitian deskriptif tentang jurnal elektronik bidang Perpusdokinfo di Indonesia, bertujuan untuk mengetahui 1) Jumlah jurnal elektronik terakreditasi, 2) Penerbit jurnal yang dibedakan menjadi a) perguruan tinggi Islam negeri dan swasta; b) perguruan tinggi negeri dan swasta; c) lembaga non perguruan tinggi; d) asosiasi profesi; 2) Kota terbit jurnal; 3) Aktif tidaknya situs jurnal; 4) Frekuensi terbit jurnal dan 5)Status akreditasi jurnal. Data dikumpulkan dari data base http://issn.pdii.lipi.go.id/ dan http:// sinta.ristekbrin.go.id dengan cara penelusuran menggunakan kata kunci perpustakaan, dokumentasi dan informasi Selanjutnya data dikelompokkan menurut tujuan penelitian. Hasil penelitian menunjukkan bahwa jumlah jurnal 41 judul, diterbitkan
\end{abstract}


oleh 37 penerbit. Sebanyak 15 judul diterbitkan oleh perguruan tinggi Islam negeri/ swasta, berikutnya 14 judul diterbitkan oleh perguruan tinggi negeri/swasta, 7 judul lembaga nonperguruan tinggi, dan 5 judul oleh asosiasi profesi. Jurnal diterbitkan di 21 kota, dan Jakarta berada pada posisi tertinggi (19,51\%), Perpustakaan Nasional Republik Indonesia menduduki peringkat pertama sebagai penerbit jurnal terbanyak (3 judul). Frekuensi terbit jurnal terbanyak adalah dua kali per tahun $(85,36 \%)$. Sejak 1 Maret 2020 sebanyak 31 situs berstatus aktif (dapat diakses), dan sisanya tidak aktif. Sebanyak 13 jurnal berstatus terakreditasi. Akreditasi tertinggi adalah SINTA 2 (3 judul). Disimpulkan bahwa jurnal perpusdokinfo elektronik sampai dengan Maret 2020 diketahui berjumlah 41 judul, diterbitkan oleh 37 penerbit. Penerbit terbanyak berasal dari perguruan tinggi negeri non Islam dan Perpustakaan Nasional Republik Indonesia merupakan penerbit terbanyak. Jakarta adalah kota terbit tertinggi. Sebagian besar frekuensi terbit jurnal adalah dua kali per tahun, tidak semua situs web jurnal elektronik dapat diakses per 11 Maret 2020, dan berdasarkan status akreditasi diketahui bahwa belum ada jurnal yang berstatus akreditasi SINTA 1 .

Kata kunci : Jurnal; Ilmu Perpustakaan dan Informasi; Akreditasi

\section{PENDAHULUAN}

Serial merupakan publikasi cetak atau non-cetak yang diterbitkan secara berseri, biasanya memuat nomor edisi, tanggal penerbitan, atau keduanya. Serial diharapkan terbit terus berlanjut tanpa batas. Serial termasuk majalah, buletin, surat kabar, laporan tahunan (seperti laporan, buku tahunan, dan direktori), jurnal, memoar, prosiding (ALCT; 2020).

Istilah 'berkala', 'serial', dan 'jurnal' digunakan secara bergantian di Perpustakaan, biasanya berarti jurnal akademis atau ilmiah. Berkala adalah istilah yang luas, artinya segala sesuatu yang diterbitkan secara berkala. Berkala ini bisa berupa koran, majalah, buletin atau jurnal.serial juga merupakan istilah dengan arti yang luas, artinya segala sesuatu yang diterbitkan secara berseri, atau dalam seri. Istilah serial paling sering digunakan untuk jurnal akademik dan merupakan publikasi yang terbit secara teratur dan berisi artikel.(UC Library; 2020).

Adapun menurut Standar Nasional Indonesia SNI 19 -1950 - 1990, yang dimaksud dengan terbitan berkala dideskripsikan sebagai berikut. Terbitan berkala adalah terbitan yang diterbitkan dalam bagian - bagian (nomor) yang berurutan dengan perwajahan dan judul sama dan terbit menurut jadwal yang sudah ditetapkan untuk waktu yang tidak ditentukan.

Apabila mengacu kepada Peraturan Menteri Riset Teknologi Dan Pendidikan Tinggi Republik Indonesia Nomor 9 Tahun 2018 Tentang Akreditasi Jurnal Ilmiah, yang disebut dengan jurnal ilmiah adalah bentuk pemberitaan atau komunikasi yang memuat karya ilmiah dan diterbitkan berjadwal dalam bentuk elektronik dan/atau tercetak. diterbitkan oleh perguruan tinggi, organisasi profesi, kementerian, lembaga pemerintah nonkementerian, lembaga penelitian \& pengembangan, lembaga pendidikan, perusahaan penerbitan, dan/atau badan usaha; dan/atau berafiliasi dengan perguruan tinggi, organisasi profesi, kementerian, lembaga pemerintah nonkementerian, lembaga penelitian dan pengembangan, lembaga pendidikan, dan/atau badan usaha.Di dalam Pasal 3 keputusan tersebut disebutkan bahwa fungsi dari jurnal ilmiah adalah meregistrasi kegiatan kecendekiaan; mengarsipkan temuan hasil kegiatan kecendekiaan ilmuwan; mengakui hasil kegiatan yang memenuhi persyaratan ilmiah; mendiseminasikan hasil kegiatan kecendekiaan; mendiseminasikan hasil pengabdian kepada masyarakat, dan melindungi hasil karya peneliti atau ilmuwan. 
Suatu jurnal disebut sebagai jurnal ilmiah apabila memenuhi persyaratan sebagai berikut; a) memuat artikel yang secara nyata memajukan ilmu pengetahuan, teknologi, dan atau seni yang didasarkan pada hasil penelitian, perekayasaan, dan/atau telaahan yang mengandung temuan dan/atau pemikiran yang orisinal, serta tidak plagiat; b) memiliki dewan editor yang berkualifikasi sesuai dengan bidang ilmu yang mewakili bidang ilmu pengetahuan, teknologi,dan atau seni; c) melibatkan mitra bestari yang berkualifikasi sesuai dengan bidang ilmu jurnal; d) menggunakan bahasa Indonesia dan/atau bahasa resmi Perserikatan Bangsa - bangsa; e) konsisten dalam format penulisan serta penampilan; f); dikelola dan diterbitkan secara elektronik; g) diterbitkan sesuai jadwal dan memiliki Electronic International Standard Number (E-ISSN) serta memiliki digital object identifier (DOI).Dalam rangka meningkatkan mutu dan relevansi jurnal ilmiah, dan daya saing Indonesia, maka dilakukan akreditasi terhadap jurnal ilmiah Indonesia. Proses akreditasi jurnal ilmiah dilakukan secara elektronik melalui jejaring teknologi informasi dan komunikasi, dilakukan oleh satu Tim Akreditasi Jurnal Ilmiah (Permenristekdikti; 2018)

Di dalam pelaksanaan akreditasi jurnal ilmiah mekanismenya mengikuti alur sebagai berikut. Pertama-tama jurnal yang akan masuk ke Science and Technology Index ( SINTA) didaftarkan melalui portal ARJUNA (Akreditasi Jurnal Nasional), url: http://arjuna. ristekdikti.go.id/. Kedua Kemenristek akan menugaskan Asesor Akreditasi untuk menilai konten dan manajemen jurnal yang masuk ke ARJUNA. Penilaian akreditasi berdasarkan pada Permenristekdikti Nomor 9 tahun 2018 dan Perdirjen Risbang no 19 tahun 2018 yang memberikan peringkat 1 hingga peringkat 6, dengan predikat SINTA 1 sampai dengan SINTA 6, (Tabel 1) (Permenristekdikti; 2018).
Tabel 1. Kategori level jurnal terakreditasi

\begin{tabular}{|c|l|}
\hline Kategori & \multicolumn{1}{|c|}{ Deskripsi } \\
\hline Sinta 1 & $\begin{array}{l}\text { Terakreditasi Peringkat } 1 \quad \text { (Satu), } \\
\text { dengan nilai akreditasi } 85 \leq \mathrm{n} \leq 100\end{array}$ \\
\hline Sinta 2 & $\begin{array}{l}\text { Terakreditasi Peringkat } \quad 2 \quad \text { (Dua), } \\
\text { dengan nilai akreditasi } 70 \leq \mathrm{n}<85\end{array}$ \\
\hline Sinta 3 & $\begin{array}{l}\text { Terakreditasi Peringkat } 3 \quad \text { (Tiga), } \\
\text { dengan nilai akreditasi } 60 \leq \mathrm{n}<70\end{array}$ \\
\hline Sinta 4 & $\begin{array}{l}\text { Terakreditasi Peringkat } 4 \quad \text { Empat), } \\
\text { dengan nilai akreditasi } 50 \leq \mathrm{n}<60\end{array}$ \\
\hline Sinta 5 & $\begin{array}{l}\text { Terakreditasi Peringkat } 5 \quad \text { (Lima), } \\
\text { dengan nilai akreditasi } 40 \leq \mathrm{n}<50\end{array}$ \\
\hline Sinta 6 & $\begin{array}{l}\text { Terakreditasi Peringkat } 6 \quad(\text { Enam), } \\
\text { dengan nilai akreditasi } 30 \leq \mathrm{n}<40\end{array}$ \\
\hline
\end{tabular}

Selanjutnya jurnal yang telah dikategorikan berdasarkan SINTA 1 sampai SINTA 6 dilakukan pemeringkatan berdasarkan jumlah sitasi dan h-indeks dari Google Scholar yang telah dibuat oleh masing-masing jurnal setelah dilakukan verifikasi.

Pada era digital saat ini banyak pustakawan, peneliti, mahasiswa maupun dosen di bidang perpustakaan, dokumentasi dan informasi yang memerlukan wadah atau sarana untuk berbagi pengetahuan dengan cara mendiseminasikan hasil-hasil penelitian mereka melalui jurnal ilmiah elektronik di bidang tersebut. Informasi tentang jurnal elektronik terutama yang sudah terakreditasi diperlukan oleh calon penyumbang tulisan dan juga oleh pengambil kebijakan di bidang riset, seperti Kementerian Riset dan Teknologi. Jurnal terakreditasi penting karena secara tidak langsung akan meningkatkan kualitas tulisan pustakawan, peneliti, mahasiswa yang akan mengirimkan tulisan mereka.ke jurnal-jurnal tersebut. Akan tetapi sampai saat ini belum ada penelitian yang menggambarkan tentang kondisi jurnal elektronik terakreditasi di bidang perpustakaan, dokumentasi dan informasi. Oleh karena itu, makalah ini dibuat dengan tujuan untuk mengetahui kondisi jurnal bidang perpustakaan, dokumentasi dan informasi yang 
sudah terakreditasi di Indonesia..Secara khusus tujuan penelitian untuk mengetahui: 1) Penerbit jurnal yang dibedakan menjadi a) perguruan tinggi Islam negeri dan swasta; b) perguruan tinggi negeri dan swasta; c) lembaga non perguruan tinggi; d) asosiasi profesi; 2) Kota terbit jurnal; 3) Aktif tidaknya situs jurnal; 4) Frekuensi terbit jurnal dan 5) Status akreditasi jurnal.

\section{TINJAUAN PUSTAKA}

\section{Science and Technology Index (SINTA)}

SINTA merupakan suatu sistem pengindeksan jurnal ilmiah nasional yang dibangun dan dikelola oleh Kementerian Riset dan Teknologi, sejak tahun 2016, saat ini beralamatkan di situs http://sinta. ristekbrin.go.id/ SINTA adalah sebuah portal yang memuat pengukuran kinerja Ilmu Pengetahuan dan Teknologi meliputi kinerja peneliti, penulis, author, kinerja jurnal dan kinerja institusi atau lembaga Iptek. S I N T A merupakan sebuah portal yang dapat secara otomatis meng-indeks hasil karya yang telah ter-indeks di Google Scholar, Scopus, InaSTI dan Indonesian Publication Index (IPI) (Amin; 2020). Adapun fungsi dasar SINTA adalah untuk memantau kinerja publikasi dosen dan peneliti, mendata publikasi dan sitasi akademisi dan peneliti Indonesia, menilai kinerja jurnal berdasarkan standar akreditasi dan sitasi, melihat analisis profil institusi, penulis dan jurnal, dan pengukuran indikator menggunakan SINTA METRIC (Lukman; 2019).

Akreditasi jurnal merupakan salah satu indikator untuk melihat kualitas dari sebuah jurnal. Khusus untuk jurnal elektronik (E-journal), faktor -faktor yang berperan dalam sebuah manajemen jurnal elektronik adalah sebagai berikut: a) Kelembagaan meliputi penanggung jawab jurnal, keberadaan riveiwer, editor dan teknologi informasi; b) Sarana dan prasarana (infrastructure) yaitu berupa perangkat lunak (Open Journal
System) dan perangkat keras (hosting/server/ backup/mirroring); c) Pendanaan/anggaran yang didedikasikan secara konsisten untuk penerbitan jurnal elektronik; d) Pemantauan kinerja jurnal, yang dapat dilihat dari statistik akses jurnal dan sitasi dari jurnal tersebut.

Hal -hal yang perlu diperhatikan dalam pengajuan akreditasi jurnal ilmiah Indonesia adalah sebagai berikut. Pertama -tama jurnal yang akan diajukan akreditasinya wajib memiliki nomor E- ISSN yang dapat diperoleh melalui Pusat Data dan Dokumentasi Ilmiah LIPI. Selanjutnya perlu dideskripsikan ruang lingkup dari jurnal, terbitan bersifat ilmiah yang diindikasikan salah satunya adalah melalui proses riview atikel. Jurnal minimal selama dua tahun secara konsisten terbit berturut-turut, dengan frekuensi terbit minimal adalah dua nomor per tahun serta memiliki digital object identifier (DOI) (Lukman; 2019)

Di dalam sistem akreditasi nasional jurnal ilmiah Indonesia, unsur - unsur yang dinilai dapat dilihat pada Tabel 1 berikut.

Tabel 1. Unsur - undur penilaian dalam akreditasi jurnal ilmiah Indonesia

\begin{tabular}{|l|c|}
\hline \multicolumn{1}{|c|}{ Unsur } & $\begin{array}{c}\text { Bobot } \\
\text { tertinggi }\end{array}$ \\
\hline Penamaan terbitan berkala ilmiah & 3 \\
\hline Kelembagaan penerbit & 4 \\
\hline $\begin{array}{l}\text { Penyuntingan dan manajemen } \\
\text { pengelolaan terbitan }\end{array}$ & 17 \\
\hline Substansi artikel & 39 \\
\hline Gaya penulisan & 12 \\
\hline Penampilan & 8 \\
\hline Keberkalaan & 6 \\
\hline Penyebarluasan & 11 \\
\hline Jumlah & 100 \\
\hline
\end{tabular}

Sumber : (Kemenristekdikti; 2018)

Di dalam memberikan penilaian, masing - masing unsur diperhatikan menurut sub unsur penilaian. Sebagai contoh, pada unsur Penamaan Terbitan Berkala Ilmiah dibagi menjadi sub unsur a) spesifik sehingga 
bisa mencerminkan super spesialisasi atau spesialisasi disiplin ilmu tertentu; b) cukup spesifik tetapi cukup meluas mencakup bidang ilmu; c) kurang spesifik dan bersifat umum; d) tidak spesifik dan/atau memakai nama lembaga/ lokasi lokal (Kemenristekdikti; 2018).

Masa berlaku akreditasi adalah selama 5 tahun, bagi jurnal yang baru mengajukan akreditasi, masa berlaku akreditasi dimulai sejak nomor terbitan yang dinilai baik, bagi jurnal yang mengajukan akreditasi ulang, masa berlaku akreditasi dimulai sejak ditetapkan. Predikat akreditasi dapat ditingkatkan, sebalum berakhirnya masa berlaku akreditasi, berdasarkan hasil evaluasi berkala, apabila kualitas jurnalnya menunjukkan peningkatan. Namun apabila terjadi penurunan kualitas jurnal, maka Direktur Jendral dapat memberikan teguran tertulis, menurunkan predikat, dan atau mencabut status akreditasi sebelum habis masa berlakunya. Di laman jurnal bagi yang sudah terakreditasi, wajib mencantumkan predikat akreditasinya di laman tersebut. (Kemenristekdikti; 2018).

\section{METODOLOGI}

Penelitian diawali dengan pengumpulan data yang bersumber dari international Standard Serial Number (ISSN) online Pusat Data dan Dokumentasi Ilmiah yang beralamatkan pada situs http://issn.pdii.lipi.go.id/issn.cgi. Database tersebut dipilih karena sampai saat ini data base tersebut merupakan sumber data jurnal yang diterbitkan di Indonesia paling lengkap dan satu-satunya di Indonesia. Seperti diketahui bahwa salah satu persyaratan untuk mendapatkan akreditasi, jurnal harus memiliki ISSN, yang hingga saat ini ISSN masih dikelola oleh Pusat Data dan Dokumentasi Ilmiah LIPI. Digunakan kata kunci "perpustakaan", dilanjutkan dengan kata kunci "informasi" dan “dokumentasi”, sebagai berikut.

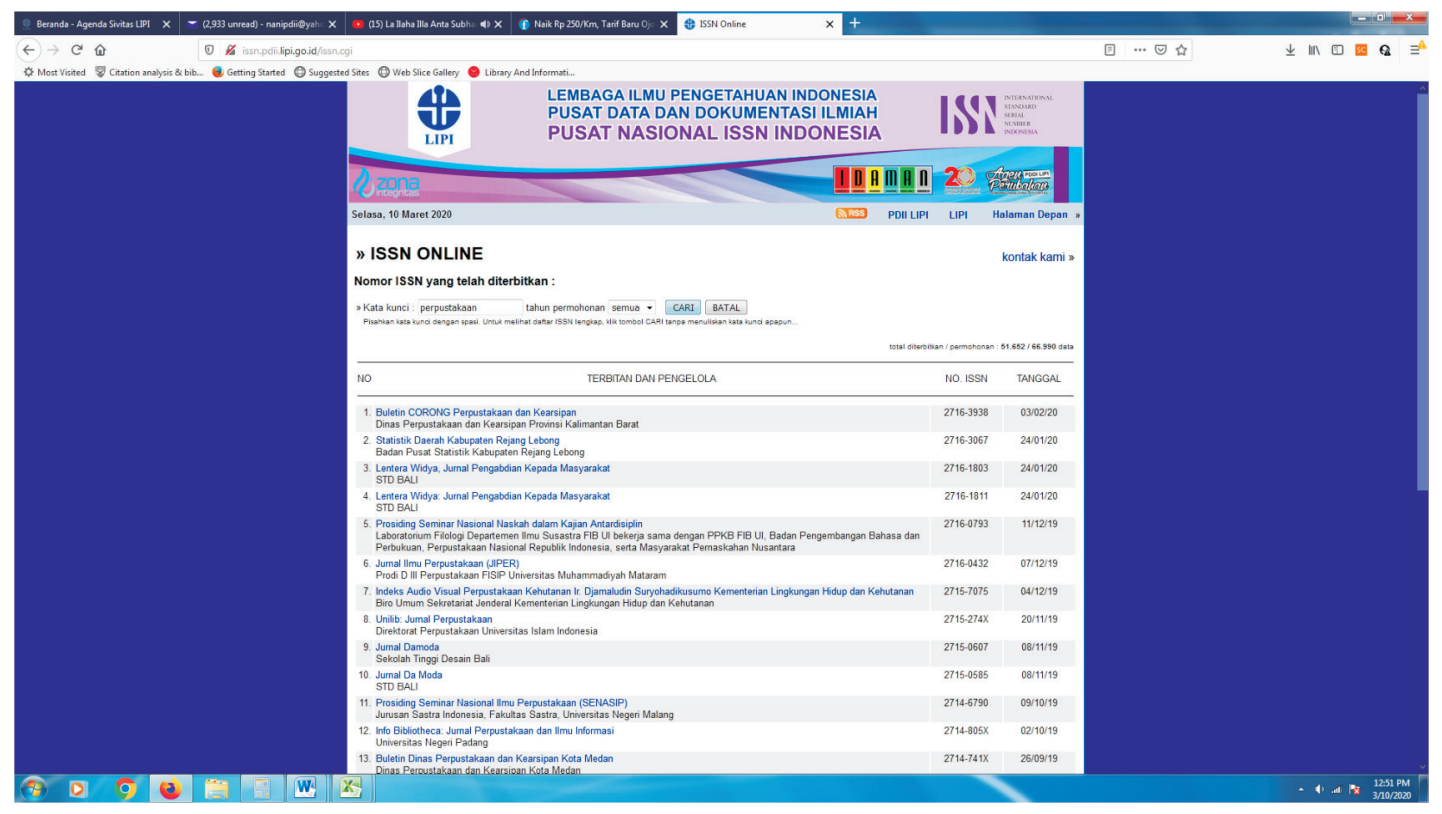

Gambar 1. Penelusuran jurnal dari database ISSN online

Pencarian data status akreditasi dilakukan dengan melakukan penelusuran Science and Technolgy Index - Sinta dari http:// sinta.ristekbrin.go.id/journals?, dengan cara memasukkan nama jurnal. 


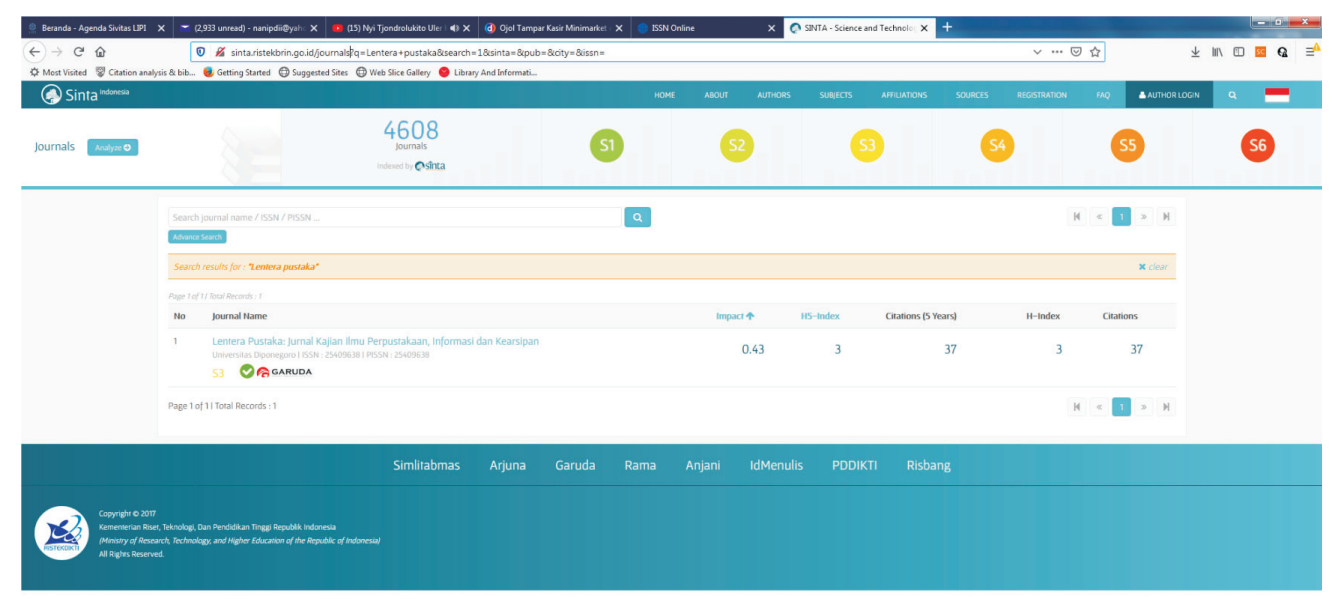

Gambar 2. Contoh penelusuran status akreditasi jurnal

Berdasarkan ke tiga kata kunci tersebut, setelah dilakukan penelusuran maka diperoleh sebanyak 41 nama jurnal bidang perpustakaan, dokumentasi dan informasi (Lampiran 1). Selanjutnya hasil penelusuran tersebut dikelompokkan sesuai dengan tujuan penelitian, yaitu : 1) Berdasarkan penerbit yang dibedakan menjadi a) perguruan tinggi Islam negeri dan swasta; b) perguruan tinggi negeri dan swasta; c) lembaga non perguruan tinggi; d) asosiasi profesi; 2) Kota terbit jurnal; 3) Aktif tidaknya situs jurnal; 4) Frekuensi terbit jurnal dan 5) Status akreditasi jurnal. Selanjutnnya data yang sudah dikelompokkan tersebut disajikan dalam bentuk tabel frekuensi, dan dihitung persentasenya, untuk dilakukan analisisnya secara deskriptif. Berdasarkan hasil analisis dan pembahasan kemudian dilakukan penarikan kesimpulan.

\section{HASIL DAN PEMBAHASAN}

1. Jurnal perpusdokinfo elektronik berdasarkan penerbit perguruan tinggi Islam

Sebanyak 10 perguruan tinggi Islam negeri menerbitkan sebanyak 11 judul jurnal, (Tabel 2) dengan perincian sebanyak 9 universitas masing-masing menerbitkan 1 judul jurnal (IAIN Bengkulu, IAIN
Padangsidempuan, IAIN Curup, IAIN Salatiga,UIN Alaudin Makassar,UIN ArRaniry Banda Aceh, STAIN Kudus dan STAIN Ponorogo). Adapun UIN Imam Bonjol Padang menerbitkan sebanyak 2 judul jurnal. Secara kuantitas jurnal yang diterbitkan oleh Institut Agama Islam Negeri (IAIN) berjumlah 4 judul, kemudian Universitas Islam Negeri (UIN) menerbitkan sebanyak 5 judul jurnal, dan Sekolah Tinggi Agama Islam Negeri menerbitkan sebanyak 2 judul jurnal.

Tabel 2.Jurnal perpusdokinfo elektronik terbitan perguruan tinggi Islam negeri

\begin{tabular}{|l|c|c|}
\hline \multicolumn{1}{|c|}{ Perguruan tinggi } & $\begin{array}{c}\text { Jumlah } \\
\text { judul }\end{array}$ & $\begin{array}{c}\text { Persentase } \\
\text { (\%) }\end{array}$ \\
\hline IAIN Bengkulu & 1 & 9,09 \\
\hline $\begin{array}{l}\text { IAIN } \\
\text { Padangsidempuan }\end{array}$ & 1 & 9,09 \\
\hline IAIN Curup & 1 & 9,09 \\
\hline IAIN Salatiga & 1 & 9,09 \\
\hline $\begin{array}{l}\text { UIN Alaudin } \\
\text { Makassar }\end{array}$ & 1 & 9,09 \\
\hline $\begin{array}{l}\text { UIN Imam Bonjol } \\
\text { Padang }\end{array}$ & 2 & 18,18 \\
\hline $\begin{array}{l}\text { UIN Ar-raniry } \\
\text { Banda Aceh }\end{array}$ & 1 & 9,09 \\
\hline $\begin{array}{l}\text { UIN Sumatera Utara } \\
\text { Medan }\end{array}$ & 1 & 9,09 \\
\hline
\end{tabular}




\begin{tabular}{|l|c|c|}
\hline STAIN Kudus & 1 & 9,09 \\
\hline STAIN Ponorogo & 1 & 9,09 \\
\hline Jumlah & $\mathbf{1 1}$ & $\mathbf{1 0 0 , 0 0}$ \\
\hline
\end{tabular}

Adapun jurnal yang diterbitkan oleh perguruan tinggi Islam swasta dapat dilihat dari Tabel 3 berikut ini. Dikethaui sebanyak 4 perguruan tinggi Islam swasta menerbitkan masing - masing sebanyak 1 judul jurnal, yaitu Universitas Muhamadiyah Ponorogo, Universitas Muhamadiyah Mataram, Universitas Islam Indonesia dan Universitas Islam Nusantara Bandung.

Tabel 3. Jurnal perpusdokinfo elektronik terbitan perguruan tinggi Islam swasta

\begin{tabular}{|l|c|c|}
\hline Perguruan tinggi & $\begin{array}{c}\text { Jumlah } \\
\text { judul }\end{array}$ & $\begin{array}{c}\text { Persentase } \\
\text { (\%) }\end{array}$ \\
\hline $\begin{array}{l}\text { Universitas } \\
\text { Muhamadiyah } \\
\text { Ponorogo }\end{array}$ & 1 & 25,00 \\
\hline $\begin{array}{l}\text { Universitas } \\
\text { Muhamadiyah } \\
\text { Mataram }\end{array}$ & 1 & 25,00 \\
\hline $\begin{array}{l}\text { Universitas Islam } \\
\text { Indonesia }\end{array}$ & 1 & 25,00 \\
\hline $\begin{array}{l}\text { Universitas Islam } \\
\text { Nusantara Bandung }\end{array}$ & 1 & 25,00 \\
\hline Jumlah & $\mathbf{4}$ & $\mathbf{1 0 0 , 0 0}$ \\
\hline
\end{tabular}

Apabila jurnal yang diterbitkan oleh perguruan tinggi Islam negeri dibandingkan dengan jurnal yang diterbitkan oleh perguruan tinggi swasta maka diperoleh nilai sebesar 11/4 yaitu sama dengan 2,75 (Tabel $2 \&$ Tabel 3). Dengan demikian jurnal yang diterbitkan oleh perguruan tinggi Islam negeri lebih banyak dibandingkan dengan jurnal yang diterbitkan oleh perguruan tinggi Islam swasta.
2. Jurnal perpusdokinfo elektronik terbitan perguruan tinggi non Islam

Jurnal bidang perpustakaan dan dokumentasi selain diterbitkan oleh perguruan tinggi Islam, juga diterbitkan oleh perguruan tinggi non Islam yang dapat dilihat pada Tabel 4.

Tabel 4.Jurnal Perpusdokinfo elektronik dari perguruan tinggi negeri dan swasta

\begin{tabular}{|l|c|c|}
\hline Perguruan tinggi & $\begin{array}{c}\text { Jumlah } \\
\text { judul }\end{array}$ & $\begin{array}{c}\text { Persentase } \\
\text { (\%) }\end{array}$ \\
\hline $\begin{array}{l}\text { Universitas } \\
\text { Diponegoro }\end{array}$ & 2 & 14,28 \\
\hline $\begin{array}{l}\text { Universitas Gajah } \\
\text { Mada }\end{array}$ & 1 & 7,14 \\
\hline Universitas YARSI & 1 & 7,14 \\
\hline $\begin{array}{l}\text { Universitas } \\
\text { Padjajaran }\end{array}$ & 2 & 7,14 \\
\hline $\begin{array}{l}\text { Universitas } \\
\text { Indonesia }\end{array}$ & 1 & 7,14 \\
\hline $\begin{array}{l}\text { Universitas Merdeka } \\
\text { Malang*) }\end{array}$ & 1 & 7,14 \\
\hline $\begin{array}{l}\text { Universitas Sebelas } \\
\text { Maret }\end{array}$ & 1 & 7,14 \\
\hline $\begin{array}{l}\text { Institut Pertanian } \\
\text { Bogor }\end{array}$ & 1 & 7,14 \\
\hline $\begin{array}{l}\text { Universitas } \\
\text { Airlangga }\end{array}$ & 1 & 7,14 \\
\hline $\begin{array}{l}\text { Universitas Negeri } \\
\text { Padang }\end{array}$ & 2 & 14,28 \\
\hline $\begin{array}{l}\text { Universitas } \\
\text { Pendidikan } \\
\text { Indonesia }\end{array}$ & 1 & $\mathbf{1 4} 14$ \\
\hline Jumlah & $\mathbf{1 0 0 , 0 0}$ \\
\hline Perginantinggi & & \\
\hline
\end{tabular}

*) Perguruan tinggi swasta

Sebanyak 14 judul jurnal bidang perpustakaan dan dokumentasi diterbitkan oleh 10 perguruan tinggi negeri dan 1 judul diterbitkan oleh perguruan tinggi swasta yaitu Universitas Merdeka Malang. Adapun Universitas Diponegoro, Universitas Padjajaran dan Universitas Negeri Padang 
masing - masing menerbitkan dua buah jurnal.

\begin{tabular}{rll}
\multicolumn{2}{c}{ Universitas } & Diponegoro melalui \\
Program Studi Ilmu Perpustakaan
\end{tabular} Fakultas Ilmu Budaya, menerbitkan Lentera Pustaka : Jurnal Kajian Ilmu Perpustakaan, Informasi dan Perpustakaan. Berikutnya Anuva, Jurnal Kajian Budaya, Perpustakaan dan Informasi, diterbitkan oleh Program Studi Ilmu Perpustakaan Fakultas Ilmu Budaya. Universtias Padjajaran menerbitkan Edulib : Journal of Library and Information Science dan Jurnal Kajian Informasi \& Perpustakaan Adapun Universitas Negeri Padang menerbitkan Info Bibliotheca: Jurnal Perpustakaan dan Ilmu Informasi dan Jurnal Ilmu Informasi Perpustakaan dan Kearsipan.

3. Jurnal perpusdokinfo elektronik terbitan dari lembaga non perguruan tinggi

Berdasarkan pada Tabel 5 berikut ini dapat diketahui bahwa penerbit yang berasal dari lembaga berjumlah 5 dengan jumlah jumlah terbitan sebanyak 7 judul jurnal. Perpustakaan Nasional Republik Indonesia berada pada posisi teratas yaitu menerbitkan sebanyak 3 judul (42,86\%), yaitu Media Pustakawan, Visi Pustaka dan Jumantara Jurnal Manuskrip Nusantara.

Seperti diketahui bahwa Perpustakaan Nasional Republik Indonesia merupakan institusi pembina seluruh perpustakaan dan pustakawan di seluruh Indonesia, dengan demikian sudah sewajarnya apabila Perpustakaan Nasional Republik Indonesia menerbitkan jurnal bidang perpustakaan dan dokumentasi terbanyak.
Tabel 5. Jurnal perpusdokinfo terbitan lembaga non perguruan tinggi

\begin{tabular}{|l|c|c|}
\hline \multicolumn{1}{|c|}{ Lembaga } & $\begin{array}{c}\text { Jumlah } \\
\text { judul }\end{array}$ & $\begin{array}{c}\text { Persentase } \\
\text { (\%) }\end{array}$ \\
\hline $\begin{array}{l}\text { Dinas Perpustakaan } \\
\text { dan Kearsipan Kota } \\
\text { Magelang }\end{array}$ & 1 & 14,29 \\
\hline $\begin{array}{l}\text { Pusat Perpustakaan } \\
\text { dan Penyebaran } \\
\text { Informasi Pertanian }\end{array}$ & 1 & 14,29 \\
\hline $\begin{array}{l}\text { Perpustakaan } \\
\text { Nasional Republik } \\
\text { Indonesia }\end{array}$ & 3 & 42,86 \\
\hline $\begin{array}{l}\text { Balitbang } \\
\text { Kementerian } \\
\text { Kelautan dan } \\
\text { Perikanan }\end{array}$ & 1 & 14,29 \\
\hline $\begin{array}{l}\text { Pusat Data dan } \\
\text { Dokumentasi Ilmiah } \\
\text { LIPI }\end{array}$ & 1 & $\mathbf{1 0 0 , 0 0}$ \\
\hline Jumlah
\end{tabular}

4. Jurnal perpusdokinfo terbitan asosiasi profesi

Sebanyak 5 asosiasi profesi pustakawan di Indonesia turut berperan aktif dalam pengembangan pengetahuan di bidang perpustakaan, dokumentasi dan informasi terbukti mereka berhasil menerbitkan publikasi ilmiah yang jurnal di bidang tersebut. Walaupun asosiasi profesi pustakawan maupun perpustakaan didominasi mereka yang berdomisili di Jawa, akan tetapi Indonesia Bagian Timur yang diwakili oleh Ikatan Pustakawan Nusa Tenggara Barat juga ikut berpartisipasi dalam penerbitan jurnal (Tabel 6). 
Tabel 6.Jurnal perpusdokinfo elektronik terbitan asosiasi profesi

\begin{tabular}{|l|l|l|}
\hline Asosiasi & $\begin{array}{l}\text { Jumlah } \\
\text { judul }\end{array}$ & $\begin{array}{l}\text { Persentase } \\
\mathbf{( \% )}\end{array}$ \\
\hline $\begin{array}{l}\text { Aosiasi Perpustakaan } \\
\text { Perguruan Tinggi } \\
\text { Islam Wilayah Jawa } \\
\text { Timur }\end{array}$ & 1 & 20,00 \\
\hline $\begin{array}{l}\text { Ikatan Sarjana Ilmu } \\
\text { Perpustakaan dan } \\
\text { Informasi }\end{array}$ & 1 & 20,00 \\
\hline $\begin{array}{l}\text { Ikatan Pustakawan } \\
\text { Nusa Tenggara Barat }\end{array}$ & 1 & 20,00 \\
\hline $\begin{array}{l}\text { Forum Perpustakaan } \\
\text { Perguruan Tinggi } \\
\text { Jawa Tengah }\end{array}$ & 1 & 20,00 \\
\hline $\begin{array}{l}\text { Ikatan Pustakawan } \\
\text { Indonesia Pusat }\end{array}$ & 1 & 20,00 \\
\hline Jumlah & $\mathbf{5}$ & $\mathbf{1 0 0 , 0 0}$ \\
\hline
\end{tabular}

\section{Kota terbit jurnal perpusdokinfo elektronik}

Sebanyak 21 kota merupakan tempat diterbitkannya ke 41 judul jurnal bidang Perpusdokinfo, dengan jumlah tertinggi adalah Jakarta yaitu menerbitkan sebanyak 8 jurnal (19,51\%). Di tempat ke dua kota Padang dengan jumlah 4 terbitan $(9,76 \%)$ dan pada posisi ke tiga adalah kota Bandung dengan jumah terbitan sebanyak $3(7,32 \%)$.

Tabel 7. Kota terbit jurnal perpusdokinfo elektronik

\begin{tabular}{|l|c|c|}
\hline \multicolumn{1}{|c|}{ Kota } & Jumlah & $\begin{array}{c}\text { Persentase } \\
\text { (\%) }\end{array}$ \\
\hline Banda Aceh & 1 & 2,44 \\
\hline Bandung & 3 & 7,32 \\
\hline Bengkulu & 2 & 4,88 \\
\hline Bogor & 1 & 2,44 \\
\hline Depok & 1 & 2,44 \\
\hline Jakarta & 8 & 19,51 \\
\hline Kudus & 1 & 2,44 \\
\hline Magelang & 1 & 2,44 \\
\hline Makassar & 1 & 2,44 \\
\hline
\end{tabular}

\begin{tabular}{|l|c|c|}
\hline Malang & 2 & 4,88 \\
\hline Mataram & 2 & 4,88 \\
\hline Medan & 1 & 2,44 \\
\hline Padang & 4 & 9,76 \\
\hline Padangsidempuan & 1 & 2,44 \\
\hline Ponorogo & 2 & 4,88 \\
\hline Salatiga & 1 & 2,44 \\
\hline Semarang & 3 & 7,32 \\
\hline Sumedang & 1 & 2,44 \\
\hline Surabaya & 1 & 2,44 \\
\hline Surakarta & 1 & 2,44 \\
\hline Yogyakarta & 2 & 4,88 \\
\hline Jumlah & $\mathbf{4 1}$ & $\mathbf{1 0 0 , 0 0}$ \\
\hline
\end{tabular}

Jakarta berada pada posisi pertama disebabkan di kota ini merupakan domisili dari Perpustakaan Nasional yang berada pada posisi tertinggi dalam menerbitkan jurnal bidang Perpusdokinfo, di samping itu Ikatan Pustakawan Indonesia Pusat, serta Ikatan Sarjana Ilmu Perpustakaan dan Informasi juga berada di Jakarta. Oleh karena itu, adalah sesuatu yang wajar apabila Jakarta berada pada urutan pertama kota terbit jurnal elektronik bidang perpusdokinfo.

6. Keaktifan dari jurnal perpusdokinfo elektronik

Aktif atau tidaknya jurnal elektronik bidang Perpusdokifo per 11 Maret 2020, dapat diketahui dari Tabel 8 berikut ini.

Tabel 8. Keaktifan jurnal elektronik bidang perpusdokinfo per 11 Maret 2020

\begin{tabular}{|l|l|l|}
\hline Akses & Jumlah & Persentase \\
\hline Dapat diakses & 31 & 75,61 \\
\hline Tidak dapat diakses & 10 & 24,39 \\
\hline Jumlah & $\mathbf{4 1}$ & $\mathbf{1 0 0}$ \\
\hline
\end{tabular}

Diketahui sebanyak 31 situs dalam kondisi aktif, bisa diakses dengan baik, adapun sisanya yaitu 10 situs dalam kondisi tidak dapat diakses per 11 Maret 2020. Kondisi tersebut dapat berubah sewaktu waktu tergantung infrastruktur serta sumber daya manusia yang mengelola jurnal 
elektronik tersebut. Kemudahan akses adalah salah satu indikator jurnal untuk mendapatkan akreditasi oleh karena itu hal tersebut perlu mendapatkan perhatian dari pengelola jurnal.

7. Frekuensi terbit jurnal perpusdokinfo elektronik

Berdasarkan Tabel 9 dapat diketahui bahwa apabila dilihat dari frekuensi terbit tertinggi, maka sebanyak 35 judul $(85,36 \%)$ merupakan jurnal dengan frekuensi terbit setahun dua kali, dan di urutan ke dua jurnal dengan frekuensi terbit tiga kali per tahun yaitu 4 judul $(9,75 \%)$ adapun jurnal dengan frekuensi terbit empat kali per tahun berada di urutan ke tiga yaitu 2 judul $(4,89 \%)$.

Tabel 9. Frekuensi terbit jurnal perpusdokinfo elektronik

\begin{tabular}{|l|c|c|}
\hline $\begin{array}{c}\text { Frekuensi terbit } \\
\text { per tahun }\end{array}$ & Jumlah & $\begin{array}{c}\text { Persentase } \\
\text { (\%) }\end{array}$ \\
\hline Dua & 35 & 85,36 \\
\hline Tiga & 4 & 9,75 \\
\hline Empat & 2 & 4,89 \\
\hline Jumlah & 41 & 100 \\
\hline
\end{tabular}

Salah satu faktor mengapa sebagian besar jurnal mempunyai frekuensi terbit dua kali dalam setahun adalah adanya kesulitan untuk mendapatkan artikel yang akan diterbitkan secara teratur.

8. Status akreditasi jurnal perpusdokinfo elektronik

Status akreditasi dari jurnal Perpusdokinfo elektronik dapat diketahu dari Tabel 10 berikut ini. Di Indonesia pemeringkatan jurnal elektronik yang dikeluarkan oleh Kementerian Riset dan Teknologi menggunakan sebutan SINTA, dengan interval SINTA 1 sampai dengan SINTA 6.
Tabel 10. Status akreditasi jurnal perpusdokinfo elektronik

\begin{tabular}{|l|c|c|}
\hline Status akreditasi & Jumlah & $\begin{array}{c}\text { Persentase } \\
\text { (\%) }\end{array}$ \\
\hline SINTA 1 & 0 & 0,00 \\
\hline SINTA 2 & 3 & 6,99 \\
\hline SINTA 3 & 0 & 0,00 \\
\hline SINTA 4 & 9 & 21,97 \\
\hline SINTA 5 & 1 & 2,43 \\
\hline SINTA 6 & 0 & 0,00 \\
\hline Belum terakreditasi & 28 & 69,29 \\
\hline Jumlah & 41 & 100 \\
\hline
\end{tabular}

Jumlah jurnal yang terakreditasi adalah sebanyak 13 judul. Status akreditasi tertinggi adalah SINTA 2 yang ditempati oleh 3 judul jurnal yaitu BACA Jurnal Dokumentasi dan Informasi terbitan dari Pusat Data dan Dokumentasi Ilmiah LIPI, Berkala Ilmu Perpustakaan dan Informasi yang diterbitkan oleh Universitas Gadjah Mada, dan Khizanah AL Hikmah; Jurnal Ilmu Perpustakaan, Informasi, dan Kearsipan. Jurnal dengan akreditasi SINTA 4 menduduki posisi teratas yaitu sebanyak 9 judul (21,97\%). Adapun jurnal dengan status belum terakreditasi diketahui sebanyak 28 judul $(69,29 \%)$.

\section{KESIMPULAN}

Berdasarkan hasil dan pembahasan dapat disimpulkan bahwa jurnal perpusdokinfo elektronik sampai dengan Maret 2020 berjumlah 41 judul, yang diterbitkan oleh 37 penerbit. Penerbit terbanyak berasal dari perguruan tinggi negeri non Islam dan Perpustakaan Nasional Republik Indonesia merupakan penerbit terbanyak. Jakarta adalah kota terbit tertinggi. Sebagian besar frekuensi terbit jurnal adalah dua kali per tahun, tidak semua situs web jurnal dapat diakses per 11 Maret 2020, dan berdasarkan status akreditasi diketahui bahwa belum ada jurnal yang terakreditasi SINTA 1 . 


\section{DAFTAR PUSTAKA}

Acosiation for Library Collection and Technical services (ALCT). (2020). What's in a Name? Presentation Guidelines for Serial Publications. http://www.ala.org/alcts/ resources/collect/serials/whatsname, diakses 06 Maret 2020.

Amin. (2020). Mengetahui Apa itu SINTA, Bagaimana Cara Mendaftar dan Fungsinya sebagai Alat Pengindeks Publikasi.https://muh-amin.com/ mengetahui-apa-itu-sinta-bagaimanacara-mendaftar-dan-fungsinya-sebagaialat-pengindeks-publikasi/, diakses 11 Maret 2020.

Badan Standarisasi Nasional. (1990). SNI 191950-1990 tentang Terbitan Berkala. Jakarta. SNI 19 -1950 - 1990.

LIPI. Pusat Data dan Dokumentasi Ilmiah. (2020). ISSN.online. http://issn.pdii. lipi.go.id/issn.cgi., diakses 10 Februari 20120.

Kemenristekdikti. (2018).Pedoman Akreditasi Jurnal Ilmiah.Dirjen Penguatan Riset dan Pengembangan Kemenristekdikti. Jakarta, 252 hal.

Lukman. (2019).Pengelolaan dan Akreditasi Jurnal Nasional.(Permenristekdikti No 9 Tahun 2018).www.kopertis3. or.id $>$ uploads.2019/02>Lukman.. diakses $11 \quad$ Maret 2020. University of Cannberra Library.(UC Library). (2020). What is the difference between a periodical, a serial and a journal?.https://canberra.libanswers. com/faq/192818, diakses 06 Maret 2020.

Sciene Technology Index_SINTA (2020).. http://sinta.ristekbrin.go.id/journals?, diakses 10 Februari 2020. 


\section{Lampiran 1.}

Daftar jurnal elektronik bidang perpusdokinfo terakreditasi per Maret 2020

\begin{tabular}{|c|c|}
\hline Jurnal & Penerbit \\
\hline Al Maktabah : Jurnal Kajian Ilmu dan Perpustakaan & IAIN Bengkulu \\
\hline $\begin{array}{l}\text { Al-Kuttab : Jurnal Kajian Perpustakaan, Informasi } \\
\text { dan Kearsipan }\end{array}$ & IAIN Padangsidimpuan. UPT Pusat Perpustakaan \\
\hline $\begin{array}{l}\text { Anuva: Jurnal Kajian Budaya, Perpustakaan, dan } \\
\text { Informasi }\end{array}$ & \begin{tabular}{|lll} 
Universitas Diponegoro. Program Studi Ilmu \\
Perpustakaan Fakultas Ilmu Budaya
\end{tabular} \\
\hline $\begin{array}{l}\text { Baca Yuk : Buletin Perpustakaan Umum Kota } \\
\text { Magelang }\end{array}$ & Dinas Perpustakaan dan Kearsipan Kota Magelang \\
\hline Berkala Ilmu Perpustakaan dan Informasi & UGM. UPT Perpustakaan \\
\hline Bibliotech : Jurnal Ilmu Perpustakaan dan Informasi & Universitas YARSI \\
\hline Bulletin Pustaka Kandaga & $\begin{array}{l}\text { Universitas Padjadjaran. Direktorat Sumber Daya } \\
\text { Akademik dan Perpustakaan }\end{array}$ \\
\hline Edulib : Journal of Library and Information Science & $\begin{array}{ll}\text { Universitas Pendidikan } & \text { Indonesia. } \\
\text { Fakultas Ilmu Pendidikan } & \\
\end{array}$ \\
\hline $\begin{array}{l}\text { IJAL (Indonesian Journal of Academic } \\
\text { Librarianship) }\end{array}$ & $\begin{array}{lll}\text { Asosiasi Perpustakaan Perguruan Tinggi Islam } \\
\text { Wilayah Jawa Timur }\end{array}$ \\
\hline $\begin{array}{l}\text { Info Bibliotheca: Jurnal Perpustakaan dan Ilmu } \\
\text { Informasi }\end{array}$ & Universitas Negeri Padang \\
\hline JIPI (Jurnal Ilmu Perpustakaan dan Informasi) & $\begin{array}{l}\text { Universitas Islam Negeri Sumatera Utara Medan. } \\
\text { Jurusan Ilmu Perpustakaan, Fakultas Ilmu Sosial }\end{array}$ \\
\hline Journal of Documentation and Information Science & $\begin{array}{l}\text { Ikatan Sarjana Ilmu Perpustakaan dan Informasi } \\
\text { Indonesia }\end{array}$ \\
\hline Jumantara: Jurnal Manuskrip Nusantara & Perpustakaan Nasional Republik Indonesia \\
\hline Jurnal Ilmu Informasi, Perpustakaan, dan Kearsipan & $\begin{array}{llll}\text { Universitas Indonesia. Departemen } & \text { Ilmu } \\
\text { Perpustakaan dan Informasi, Fakultas } & \text { Ilmu } \\
\text { Pengetahuan Budaya } & & \\
\end{array}$ \\
\hline Jurnal Ilmu Perpustakaan (JIPER) & $\begin{array}{l}\text { Universitas Muhammadiyah Mataram. Prodi D III } \\
\text { Perpustakaan FISIP }\end{array}$ \\
\hline Jurnal Ilmu Informasi Perpustakaan dan Kearsipan & $\begin{array}{l}\text { Universitas Negeri Padang. Program Studi } \\
\text { Informasi Perpustakaan dan Kearsipan, Jurusan } \\
\text { Bahasa dan Sastra Indonesia dan Daerah, Fakultas } \\
\text { Bahasa dan Seni }\end{array}$ \\
\hline $\begin{array}{l}\text { Jurnal Imam Bonjol : Kajian Ilmu Informasi dan } \\
\text { Perpustakaan }\end{array}$ & $\begin{array}{l}\text { Universitas Islam Negeri Imam Bonjol Padang. } \\
\text { Perpustakaan Pascasarjana }\end{array}$ \\
\hline Jurnal IPI (Ikatan Pustakawan Indonesia) & Ikatan Pustakawan Indonesia (IPI) Pusat \\
\hline Jurnal Kajian Informasi \& Perpustakaan & $\begin{array}{l}\text { Universitas Padjadjaran Bandung. Program Studi } \\
\text { Ilmu Perpustakaan, Fakultas Ilmu Komunikasi }\end{array}$ \\
\hline Jurnal Literasi Pustakawan & Ikatan Pustakawan Indonesia Nusa Tenggara Barat \\
\hline $\begin{array}{l}\text { Jurnal Manajemen : Untuk Ilmu Ekonomi dan } \\
\text { Perpustakaan }\end{array}$ & Universitas Merdeka Malang. Perpustakaan \\
\hline Jurnal Perpustakaan Pertanian & $\begin{array}{l}\text { Pusat Perpustakaan dan Penyebaran Tekonologi } \\
\text { Pertanian Bogor }\end{array}$ \\
\hline Jurnal Pustaka Ilmiah & $\begin{array}{l}\text { Universitas Sebelas Maret Surakarta . UPT } \\
\text { Perpustakaan }\end{array}$ \\
\hline
\end{tabular}




\begin{tabular}{|c|c|}
\hline Jurnal Pustakawan Indonesia & Perpustakaan IPB \\
\hline $\begin{array}{l}\text { Khizanah al-Hikmah : Jurnal Ilmu Perpustakaan, } \\
\text { Informasi, dan Kearsipan }\end{array}$ & $\begin{array}{l}\text { Universitas Islam Negeri Alauddin Makassar. } \\
\text { Fakultas Adab Dan Humaniora }\end{array}$ \\
\hline $\begin{array}{l}\text { Lentera Pustaka: Jurnal Kajian Ilmu Perpustakaan, } \\
\text { Informasi dan Kearsipan }\end{array}$ & \begin{tabular}{|llll} 
Universitas Diponegoro. Program Studi & Ilmu \\
Perpustakaan Fakultas Ilmu Budaya & & \\
\end{tabular} \\
\hline Libraria : Jurnal Ilmu Perpustakaan dan Informasi & FPPTI Jawa Tengah \\
\hline LIBRARIA: Jurnal Perpustakaan & $\begin{array}{l}\text { Sekolah Tinggi Agama Islam Negeri (STAIN) } \\
\text { Kudus. Perpustakaan }\end{array}$ \\
\hline LIBRIA : Library of UIN Ar-Raniry & Universitas Islam Negeri Ar Raniry. Pascasarjana \\
\hline Media Pustakawan & $\begin{array}{l}\begin{array}{l}\text { Perpustakaan Nasional, Pusat Pengembangan } \\
\text { Pustakawan }\end{array} \\
\end{array}$ \\
\hline $\begin{array}{l}\text { Nusantara Journal of Information and Library } \\
\text { Studies (N-JILS) }\end{array}$ & $\begin{array}{llll}\text { Universitas Islam Nusantara. } & \text { Prodi } & \text { Ilmu } \\
\text { Perpustakaan dan Informasi } & & \end{array}$ \\
\hline $\begin{array}{l}\text { PUBLIS (Publication Library and Information } \\
\text { Science) }\end{array}$ & Universitas Muhammadiyah Ponorogo \\
\hline $\begin{array}{l}\text { Pustabiblia : Journal of Library and Information } \\
\text { Science }\end{array}$ & $\begin{array}{l}\text { Institut Agama Islam Negeri (IAIN) Salatiga. Unit } \\
\text { Pelaksana Tugas (UPT) Perpustakaan }\end{array}$ \\
\hline $\begin{array}{lllll}\text { Pustakaloka : Jurnal Kajian Informasi dan } \\
\text { Perpustakaan }\end{array}$ & $\begin{array}{l}\text { Sekolah Tinggi Agama Islam Negeri (STAIN) } \\
\text { Ponorogo }\end{array}$ \\
\hline Record and Library Journal (e-Journal) & Universitas Airlangga. Prodi Teknisi Perpustakaan \\
\hline $\begin{array}{l}\text { Shaut Al-Maktabah : Jurnal Perpustakaan, Arsip } \\
\text { dan Dokumentasi }\end{array}$ & $\begin{array}{l}\text { UIN Imam Bonjol Padang. Program Studi Ilmu } \\
\text { Perpustakaan }\end{array}$ \\
\hline Tik Ilmeu : Jurnal Ilmu Perpustakaan dan Informasi & IAIN Curup. Pusat Penerbitan dan Publikasi Ilmiah \\
\hline Unilib: Jurnal Perpustakaan & Universitas Islam Indonesia DirektoratPerpustakaan \\
\hline $\begin{array}{l}\text { Visi Pustaka: Buletin Jaringan Informasi Antar } \\
\text { Perpustakaan }\end{array}$ & Perpustakaan Nasional Republik Indonesia \\
\hline Jurnal Pari & Balitbang KP \\
\hline BACA: Jurnal Dokumentasi dan Informasi & Pusat Dokumentasi dan Informasi Ilmiah - LIPI \\
\hline
\end{tabular}

